\title{
THE OPPRESSION REMEDY FOR MINORITY SHAREHOLDERS
}

\author{
L. M. SCHAEF*
}

The author gives an overview of some of the new remedies available to the minority shareholder with the Alberta Business Corporations Act. She pays particular attention to whether these new remedies allow the Court too much freedom to interfere with the internal workings of the company.

\section{INTRODUCTION}

A minority shareholder's position in a corporation has traditionally been a position wielding minimal power. The rule of the majority could leave a minority shareholder in an oppressed state with no alternative but to sell his shares. If the corporation was closely held even this alternative was somewhat illusory as the limited market would be a restrictive factor on the price he could obtain for his shares. A derivative action on behalf of the corporation could be attempted, but if the wrong was to the shareholder and not to the shareholder via the corporation, this action was of no avail to him. Some degree of protection for the minority shareholder has long been seen as desirable and has been introduced through the new oppression remedies of a number of business corporations acts across Canada. The provisions on their faces appear inordinately wide and consequently have raised concerns that they will hamper the majority from acting in ways sanctioned in the past by good business practice. The purpose of this paper is to take a close look at how the courts have interpreted the aim and scope of the oppression remedies and examine the ef fect that has been given to their curative aspects.'

\footnotetext{
The foundation of it all lies in the words "just and equitable" . . The words are a recognition of the fact that a limited company is more than a mere legal entity, with a personality in law of its own: that there is room in company law for recognition of the fact that behind it, or amongst it, there are individuals, with rights, expectations and obligations inter se which are not necessarily submerged in the company structure.
}

The above quote was taken from the judgement of Lord Wilberforce in Ebrahimi v. Westbourne Galleries Ltd. ${ }^{2}$ Lord Wilberforce places great faith in the proposition that the interest of shareholders should not be trammelled by those in a position of advantage over them. Given that the oppression remedies introduced in Canada in the last twelve years are said to be the most liberal provisions in the common law world, ${ }^{3}$ one would have thought that we in Canada should have far surpassed the equitable remedies granted to oppressed corporate minorities in the past. In fact this very hypothesis is one that has troubled certain writers, in the apprehension that the courts may overstep their bounds in an heretofore untampered-with area. ${ }^{4}$ Have we seen the last of the non-interference doctrine? On which guidelines will the courts rely for their inside business

- Articling with the firm of MacKimmie Matthews in Calgary.

1. Ebrahimi v. Westbourne Galleries Ltd. et al. [1973] A.C. 360, [1972] 2 W.L.R. 1289 (H.L.).

2. Supra n. 1 at $379 ; 1297$.

3. S.M. Beck, "Minority Shareholders' Rights in the 1980s" (1982) Special Lectures of the Law Society of Upper Canada 311 at 312.

4. M.A. Waldron, "Corporate Theory and the Oppression Remedy" (1982) 6 Canadian Business Law Journal 129 at 130. 
decisions in these new murky waters? Are we really that close to the unreined interference that some writers fear? The minority shareholder, although one step ahead in his ability to pursue compensation for wrongs on his own account, has yet to bring the tyranny of the majority to its knees.

In this paper I suggest that there have been only limited changes for minority shareholders since the introduction of the relevant oppression remedies. The cases which are cited as being progressive, or even pushing matters a bit beyond the mark, ${ }^{5}$ depending on one's outlook, have been decided on remarkably similar grounds to some pre-existing common law doctrine, or contemplated specifically in some other part of the Acts. They can be distinguished on this basis as not supporting a majorityminority duty.

\section{LEGISLATIVE PROVISIONS}

The oppression remedy for shareholders saw its beginnings in s. 210 of the 1948 U.K. Companies Act. ${ }^{6}$ Applicants under s. 210 had to first prove grounds for a winding-up of the company and then show that under the circumstances of their case, a dissolution would be unfair or prejudicial to some of the shareholders. This made them eligible for alternative remedies. A study on s. 210 done by the Jenkins Committee found that it was unnecessary to tie the oppression remedies to the provisions for winding-up. They also thought that the grounds for oppression should be widened and that liability should attach on the basis of a single act as well as on a continuing course of conduct by the company. These suggestions were all accepted in the drafting of the Canadian provisions for the oppression of minority shareholders.

Today, if a complainant feels that his interests in a corporation are, or have been oppressed in some manner, he may apply to the court for an order chosen from a variety of remedies under s. 234 of the Canada Business Corporations $\mathrm{Act}^{8}$ or s. 234 of the Alberta Business Corporations Act. ${ }^{9}$ Any reference to the corporation in these sections also includes its affiliates. Liability will be found if there has been any act or ommission of the corporation or its directors that is "oppressive" or "unfairly prejudicial" to, or "unfairly disregards" the interests of any security holder, creditor, director, or officer. ${ }^{10}$

The potential power to remedy wrongs that these sections bring the shareholder is incredibly wide-sweeping on a strict analysis of the wording of the relevant sections. First, the definition of "complainant" as someone who may apply to the court for redress encompasses almost anyone who has a passing interest in the corporation. Under s. 231

5. See Beck, supran. 3 at 316; and Waldron, supran. 4 at 145.

6. Companies Act, 1948 (U.K.), c. 38.

7. Report of the Jenkins Committee, Command Papers, 5th series, 1749.

8. Canada Business Corporations Act, S.C. 1974-75-76, c. 33, s. 234 as am. S.C. 1978-79, c. 9. s. 74.

9. Alberta Business Corporations Act, S.A. 1981 c. B-15.

10. This is true in the Alberta and Canada Business Corporations Acts, but the British Columbia Company Act, R.S.B.C. 1979, c. 59, s. 224, does not include "unfairly disregards the interests of" in addition to "oppressive" and "unfairly prejudicial" conduct. 
"complainant" includes any shareholder, director, or officer, as well as any past shareholder, director, or officer. But beyond this, it includes any other person who, in the discretion of the court, is a proper person to make application under the remedies part of the Act. We next see a wide category of conduct that can be brought under suspicion. Any acts, omissions, or the carrying on of the affairs of the corporation, plus the exercise of the power of the directors, will be subject to scrutiny. All subsidiaries of the corporation risk review of the same intensity. The conduct must not be classified as any of three types: oppressive, unfairly prejudicial, or of a manner which unfairly disregards the minority shareholder's interests.

It appears that the minority shareholder is fully protected now. A progressive step considering that his prior position was only to take an action through and on behalf of the corporation. " There seem to be no remedies that he could possible desire which have not been contemplated under s. 234. Concern is caused, however, by just this breadth of the wording of the section and the creation of an onerous duty flowing from majority to minority shareholders is what is feared. Nevertheless, an examination of the case law will show that the courts have not yet used the full scope of the section, but rather have taken an approach that ties the section to the basics of corporate law in the past.

The successful Canadian cases in the past ten years based on the oppression remedy seem naturally to fall into four groups. First, are cases of forced amalgamations aimed at squeezing-out minorities who refuse to sell their shares in response to take-over bids. Second, are actions concerning wrongs within closely held corporations, which actions have found success on their apparent analogy to the partnership structure. Third, are cases in which directors have been stopped from misusing corporate property or from neglecting the best interests of the corporation in the exercise of their discretion with a view to their own gain. Finally, there is a group of cases which on first inspection seem to demand a near fiduciary duty of the majority shareholder to the minority. ${ }^{12} \mathrm{My}$ thesis is that an analysis of these four categories shows that the courts are either basing liability for oppression on substantially the same considerations as during the pre-234 era, or, on a specific statutory provision other than s. 234.

\section{AMALGAMATIONS}

To discuss the amalgamation cases it is necessary to have an awareness of the special provisions for take-overs in the Alberta and Canada Business Corporations Acts. If a bidder acquires ninety per cent of either a corporation's shares, or of the targeted class of shares, he can force the remaining of ferees to sell him their shares. The transaction can be at an agreed price of fair market value or at a figure determined under the ap-

11. In the form of a derivative action which requires court approval. However, the standards set by the court to grant leave for a derivative action will not be as rigorous as those set for the proof of the case on its merits in an action under s. 234 .

12. Beck, supra n. 3 at 317. 
praisal section of the Act. ${ }^{13}$ When the object is to gain complete control of the corporation, the bid will, of course, be for all classes of shares and on a ninety per cent response, a successful take-over is possible under $\mathrm{s}$. 199. Three cases dealing with applications brought under s. 234 of the Canada Business Corporations Act to restrain amalgamation attempts effecting a take-over are Alexander v. Westeel-Rosco Ltd., ${ }^{14}$ Ruskin v. Canada All News Radio Ltd. ${ }^{15}$ and Burdon v. Zeller's Ltd. ${ }^{16}$ In Alexander v. Westeel-Rosco and Burdon v. Zeller's it is clear that a bid of the type contemplated by s. 199 was attempted and had failed. In Ruskin v. Canada All-News Radio the case report does not clarify this point, but one suspects that here also, the first attempt at a take-over would have been in a manner that was sanctioned by the Act.

The gist of these cases is that a merger of " $A$ " Corporation with " $B$ " Corporation, owned solely by the majority of " $A$ ", is simply an attempt to oust a minority who could not be bought out under the ninety per cent rule. ${ }^{17}$ By using the technique of an amalgamation squeeze-out the purchasing company is trying to achieve indirectly that which could not be accomplished in a direct and approved manner. Judicial intervention can be explained on the grounds that the courts have never been fond of such round-about achievements. ${ }^{18}$ The courts do appear, however, to attach some relevance to a small minority preventing a move that would be in the best interests of the corporation, but in none of the cases was a sound business reason for the take-over found. The potential damages to be suffered by the minority if forced to sell against their will were held to be "irreparable", as a loss of future profits would be next to impossible to calculate. The problem posed, as figuratively stated by Montgomery J. in Westeel-Rosco, was: "How do you unscramble an egg?"..19

In each case, a restraining injunction was granted to prevent the planned mergers from occurring and squeezing out the minority shareholders. Clearly the remedies granted in these cases show a paternal concern for the oppressed minority, but can this be viewed as a drastic extension of the court's powers through $\mathrm{s}$. 234? It has been suggested that these cases ${ }^{20}$ affirm the existence of an everpresent shareholder's right to maintain his

13. Supra n. 8, s. 184, where the holder of shares of any class of a corporation may dissent if the corporation is to amalgamate with another corporation which is not an extra-provincial wholly owned subsidiary, or the subsidiary of the corporation if it is a holding corporation. The shareholder is then entitled to be paid by the corporation the fair value of the shares held by him in respect of which he dissents.

14. (1978) 93 D.L.R. (3d) 116, 22 O.R. (2d) 211,4 B.L.R. 313 (H.C.).

15. (1979) 7 B.L.R. 142 (Ont. H.C.).

16. (1981) 16 B.L.R. 59 (Que. S.C.).

17. This result can be obtained through a special resolution on amalgamation which can be passed by a two-third's majority of "A", pursuant to s. 177. Under the resolution " $A$ " shareholders will receive non-voting redeemable preference shares which will promptly be redeemed. All of "A" shares will be redeemed so that the resolution will apply equally to all shareholders. The advantage will be in the majority of "A" also owning " $B$ ", which leaves them in a position of total control.

18. Any attempts under s. 177 of the Canada Business Corporations Act were meant to be executed in good faith.

19. (1978) 4 B.L.R. 313 at 328.

20. Westeel-Rosco, supra n. 14, and Ruskin v. Canada All News Radio, supra n. 15, in particular. 
position in a corporation. ${ }^{21}$ This right would prevail in the absence of either a statutory provision removing it, or a sound business reason for the squeeze-out. The effect of s. 234 is not nearly as widesweeping as these suggestions would lead one to believe. Rather than a positive duty of the involved parties to protect the shareholder's standing, there is, in effect, a negative proviso in the Act stating that a forced take-over of minority shares will not be allowed if it is based on anything less than a ninety per cent holding. The courts will not allow someone to accomplish through devious routes that which the Act has impliedly forbidden in a specific section. Section 234 simply does not give shareholders an unencroachable right to protect their share position. It is more accurately seen as a vehicle through which to protect rights granted under other specific sections of the Acts.

\section{THE QUASI-PARTNERSHIP DOCTRINE}

The second set of cases to be examined fall under the realm of a doctrine existing prior to much of the Canadian litigation based on the oppression remedies as we now know them. Ebrahimi v. Westbourne Galleries $L t d$. was decided on a quasi-partnership basis by the House of Lords in 1972 and our courts have seemed to favour the doctrine as being "fair and equitable". The theory encompasses people involved in corporate entities founded on the basis of previously held partnerships or similar arrangements consisting of firmly entrenched ideas as to participation in management. Ebrahimi says that the participation expectations should not be fettered or destroyed by the detached mechanisms of the corporate entity.

In the case of Diligenti v. RWMD Operations Kelowna Ltd..$^{22}$ there were four men who began a business to run restaurants on a partnership basis and subsequently incorporated on the understanding that equal participation in the control of the business would continue. A later falling out among the four resulted in one being ousted from management participation and removed as director. The directors' fees to the other three were raised shortly thereafter and a management fee of two and one half per cent of gross sales per month was diverted to a management company wholly owned by the three in the majority. The Court did not hesitate to look into the background of the venture. Since Ebrahimi had been decided on the ground of what was "unjust and inequitable" for the purposes of winding-up, Fulton J. had to deal with the equivalence, if any, of the meaning of "unfairly prejudicial" under s. 221 of the British Columbia Companies Act. ${ }^{23} \mathrm{He}$ turned to a study of dictionary definitions and concluded that it was ". . . significant that the dictionary definitions support the instinctive reaction that what is unjust and inequitable is obviously also unfairly prejudicial". ${ }^{24}$ It appears, then, that the same conduct will

21. Waldron, supra n. 4 at 147-148.

22. (1976) 1 B.C.L.R. 36 (S.C.).

23. The Companies Act, 1973 (B.C.), c. 18.

24. Supran. 22 at 46. 
be actionable under our advanced oppression remedies as was actionable under the winding-up provisions previously available. The corporation was required to buy Diligenti's shares at a fair value calculated at a time prior to any of the questioned occurrences.

A question remaining unanswered as of yet, is whether the Alberta and Canada business corporations acts will be more lenient in their granting of relief because of the difference in the wording of the sections compared to the British Columbia Company Act. ${ }^{25}$ Will "unfairly disregards" be held to encompass conduct less reprehensible than "oppressive" or "unfairly prejudicial"? The courts will most likely rely on their basic reaction to what is unjust and inequitable and the modifier, "unfairly", will be what determines the conduct's fate, as opposed to whether it is "prejudicial" or merely "disregarding". It is unlikely that conduct disregarding someone's interests will be categorized as "unfair" if their rights or interests are not prejudiced as well.

Re Sabex Internationale L tee. ${ }^{26}$ is a quasi-par tnership case misguidedly relied on by proponents of the view that the new oppression remedies have created and been used to enforce a duty owed to the minority from the majority. Sabex, a pharmaceutical manufacturer, was formed by the combination of two businesses on an equal management footing, with a right of first refusal granted on each other's shares. Subsequent developments resulted in a reorganization of the share structure with a holding of fifty-four per cent by one of the groups. To obtain further equity a rights of fering was made to existing shareholders at the subscription rate of five cents per share. The minority objected to the of fering on the grounds that they would be forced to buy new shares in order to prevent a dilution of their presently held capital. The Court disallowed the offering on the basis of s. 234 of the Canada Business Corporations Act. Examining the background of the corporation proved that the two shareholder groups had participated equally in control and decisionmaking from the outset. ${ }^{27}$ This was enough to bring the case under the quasi-partnership doctrine as pronounced in Ebrahimi.

It has been suggested ${ }^{28}$ that this case moves the Canadian courts a giant step into the area of fiduciary duties running from majority to minority shareholders, as is presently the system in America; but this analysis is not founded on the facts of the case. Re Sabex was decided on a quasipartnership basis and has no more suggestion in it of majority fiduciary duties than does Diligenti. ${ }^{29}$ These actions could have obtained the same results on applications under s. 185 of the British Columbia Company Act, the equivalent of England's s. 210, and are not attributable to the new oppression remedies under s. 224 in British Columbia or s. 234 in the Canada Business Corporations Act.

25. The Companies Act, R.S.B.C. 1960, c. 67, s. 185.

26. (1979) 6 B.L..R. 65.

27. The Court did not find that the slight change in share structure suggested the intent of a reorganization of participation in management.

28. Beck, supran. 3 at 317; and Waldron, supra n. 4 at 145-146.

29. Granted that Diligenti dealt with individuals and a previous partnership arrangement, but the concepts of participation in management and the understanding of the parties on initial incorporation are identical in $R e$ Sabex and can apply equally as well to a representative group as to separate individuals. 
If the majority-minority duty theory is pressed to its natural conclusion, the minority shareholder would be able to enforce obligations owed to him in good faith by the majority in a regular corporate situation, not protected by the quasi-partnership umbrella. This is clearly not the position of our corporate law today. In the case of Johnston v. West Fraser ${ }^{30}$ the majority made promises to a minority shareholder which they did not keep. These promises offered Johnston an enhanced position of power and influence within the corporation and an increased market for his shares on fulfilment of the corporation going public. Johnston applied for relief under s. 224 of the British Columbia Company Act. At first instance he was granted an order for the purchase of his shares by the corporation at an estimated price that would have applied had the company gone public; a price presumed to be substantially higher than regular book value. However, on appeal, this decision was overturned. ${ }^{31}$ It was held that the establishment of the obligations owed by the majority substantiated nothing beyond a private agreement.

The result in West Fraser may foreshadow the different treatment cases can be expected to receive if they cannot bring themselves within the incorporated partnership doctrine of Ebrahimi. 32 Of course, in Johnston v. West Fraser the majority were accused of oppressive conduct, but had the majority owed duties of an anywhere near fiduciary capacity, the appeal decision would have gone the other way. Reinforced, is the influential weight of the analogy to the partnership structure that settled cases like $\operatorname{Re}$ Sabex and Diligenti, and dispelled, is the notion that these cases were decided on the basis of a majority fiduciary duty or a guarantee flowing to all minority shareholders protecting their share positions. Not much has changed. ${ }^{33}$

30. (1981) 29 B.C.L.R. 379 (S.C.).

31. (1982) 37 B.C.L.R. 360 (C.A.).

32. The trial decision simply relied on the oppressive conduct of the majority shareholders.

33. For further support of this point see also Re Ferguson and Imax Systems Corp. (1983) 43 O.R. (2d) 128 (C.A.) and Journet v. Superchef Food Industries [1984] C.S. 916.

In Re Ferguson and Imax Systems Corp., p. 137 and 138, Brook J.A. stated that “. . . when dealing with a close corporation, the court may consider the relationship between the shareholders and not simply legal rights as such ... Here we have a small close corporation that was promoted and is still controlled by the same small related group of individuals ... The appellant cannot be considered like someone who came to the company lately and took a minority position in one of several classes of stock." Consequently, an application under s. 234 of the Canada Business Corporations Act, supra n. 8, was successful, and an injunction was granted to prevent a reorganization of the corporate share structure, which would have made the applicant's preference shares redeemable.

An applicant under s. 234 of the Canada Business Corporations Act, in Superchef was granted an order which provided for the appointment of a receiver-manager, the removal of the offending director, and the cancellation of resolutions and agreements which the same director had improperly approved. The judgement reads, at 919, that a "kind of corporate partnership had been created and it had been specifically agreed that each partner would have to agree on all matters to do with the operation and administration of both companies." The fifty-fifty balance was disturbed when the respondent director neglected to take measures to fill the other position on the board of directors when it became vacant. He continued from this point to make independent business decisions, ignoring the best interests of the corporation. The court disapproved of this disruption of the initial agreement to share equally in management and control. 


\section{DIRECTORS' LIABILITIES}

An area that has seen more development, is the way in which shareholders can use the Act to force directors to live up to their obligations. It has always been held that directors owe their fiduciary duties to the corporation and not to the shareholders. ${ }^{34}$ This theory permitted acts of bad faith to be ratified by the corporation when the directors naturally refused to pursue compensation for the wrongs. The derivative action ${ }^{35}$ was seen as a means of overcoming these problems as it allowed the shareholder to initiate an action on the corporation's behalf, as long as he secured court approval. The shareholder's action under the new oppression sections is one step removed from this, as an oppression action can be initiated without court approval and can furnish the shareholder with a host of available remedies, making it in this sense, a superior protection. It is suggested once again, however, that the considerations on which the courts are granting relief in this area are not based on any newly-established reasons for court interference to protect minorities, but rather on the basis of an analogy to a pre-existing duty of the directors to the corporation.

Three cases which deal with the control of directors are Re Peterson and Kanata Investments Ltd., ${ }^{36}$ Redekop v. Robco Construction Ltd., ${ }^{37}$ and Inversiones Montforte S.A. v. Javelin International Ltd. ${ }^{38}$ In Kanata, a director regained control of a company by threatening to cease all financial support for it. He later used his majority holding in Kanata to enter into a take-over agreement concerning a company called Empire, shares of which were Kanata's major asset. A handsome reward was received by the director from the bidding company for giving up his management position in Empire. In partial return for this he undertook to ensure that Kanata's Empire shares would be sold to the new group at a price which he had previously deemed to be too low. After the sale he intended to use his control position to cause Kanata to be wound-up. The director happened to own other Empire shares held by a third company which were also sold to the take-over group, but at a profit to the director of thirty-five thousand dollars. The result of the whole transaction was that the minority shareholders stood to make fifty cents back on their dollar of initial investment in Kanata after selling the company's major asset and winding-up.

On an application under s. 221 of the British Columbia Company Act the Court held that the director was to sell his controlling shares back to Kanata. The transaction was to take place at the same token price that he had obtained the shares for in a manner that was lacking ". . . an appropriate air of bona fides", ${ }^{39}$ and advantageous to no one but himself. The shareholders of Kanata could then elect a new board of directors and

34. Percivalv. Wright [1902] 2 Ch. 421.

35. Canada Business Corporations Act, supra n. 8, s. 232, and Alberta Business Corporations Act, supra n. 9, s. 232.

36. (1975) 60 D.L.R. (3d) 527 (B.C.S.C.).

37. (1978) 89 D.L.R. (3d) 507; 7 B.C.L.R. 268 (S.C.).

38. (1982) 17 B.L.R. 230 (Que. S.C.).

39. Supran. 35 at 544 . 
be free from their oppressor's control. The contract which the director had negotiated was obviously not in the best interests of Kanata, and since the director stood to gain from it personally, there was a clear conflict of duty. The minority shareholders were to suffer an economic loss as a result. The limitations that Kanata placed on the director's acts are not new; the same acts would equally succeed in attaching liability under a derivative action on the basis of an accounting due to the corporation. The duty owed is the steadfast fiduciary duty of the director to the corporation. ${ }^{40}$ The innovative change has come in the method of enforcement: the new oppression remedies have eliminated the corporation as financial middleman and have permitted the shareholder to obtain direct relief.

The remedy granted in Redekop serves as a more accurate illustration of this point. The director, Robillard, took a forty-nine per cent share in another company and then caused Robco Construction to enter into a contract with the new company on a cost plus five per cent basis. Robillard failed to fulfil the disclosure obligations imposed by the Act in just such cases of conflict of interest. The court invoked s. 221 of the British Columbia Company Act and ordered Robco Construction to purchase the applicant's shares. This is admittedly a more far-reaching remedy than could be obtained through the derivative action, nevertheless, it is suggested that the reasons for liability remain the same. Robco has been said to be a ". . . classic breach of fiduciary case" ${ }^{41}$ It is precisely this point which emphasizes the fact that the courts exercise no new restraints over directors' powers.

A third example is found in Inversiones Montforte. We see the directors here spending millions of dollars to maintain the status quo during a control struggle. We also see the funnelling off of two million dollars to one director as a combination of "consulting fees" and personal income tax aid. A receiver-manager was appointed by the Court to monitor Javelin's affairs. Once again, an innovative remedy, however, any suggestion that the conduct of the directors would have been sanctioned prior to the oppression remedies would be absurd. The new court interference is found in the cure, certainly not in the control, and none of the remedies has yet to appear revolutionary.

\section{MAJORITY-MINORITY DUTY}

When we study further cases which on first analysis could support the previously discussed majority-minority duty, we see how crucial the link to the past through director liability really is in Canada. A review of three

40. In Bernard v. Valentini (1978) D.L.R. (3d) 440 (Ont. H.C.) an injunction was granted to minority shareholders which prevented the sole director of the corporation from exercising any rights flowing to him from shares which had been issued under questionable circumstances and had placed him in a majority sharcholder position. This illustrates the enforcement of a director's fiduciary duties to the corporation, without the aid of an oppression remedy, which was only enacted in Ontario in 1982.

For examples of similar duties being enforced through the medium of the new oppression remedies, especially concerning conflict of duty situations, see Re Ferguson and Imax Systems Corp., supra n. 33; Journet v. Superchef, supra n. 33; and Miller v. Mendel Holdings [1984] 2 IV.W.R. 683 (Sask. Q.B.).

41. Beck, supran. 3 at 318 . 
cases is necessary to substantiate this point. Re Little Billy's Restaurant (1977) Ltd., ${ }^{42}$ the most recent of the three, contains some of the strongest statements supporting this proposition. The applicant, under s. 224 of the British Columbia Company Act, owned thirty-eight per cent of Little Billy's Restaurant and held a management position. The respondents held the majority of directorships and owned sixty-two per cent of the shares. They also owned the company which granted the Little Billy's franchises and conducted advertising and promotional activities for the restaurants. Little Billy's owed nothing on this account and there had been no franchising fee charged for the years of 1977 to 1981. In 1982, the majority of the directors, with the applicant opposed, passed a resolution approving a franchise agreement. The arrangement was for the payment of three per cent of the restaurant's gross sales to the franchise company. The net profit of the restaurant had recently only been reaching a height of two per cent of the gross sales.

The court held that the diversion of the funds as franchise fees directly affected the applicant's rights as a shareholder of the company as it excluded his participation in that portion of the income. The interesting suggestion of the Court, however, was that if the diverters of the funds had been mere majority shareholders, and not occupants of directorial positions, the Court could not have held them liable. Wallace J. remarked that shareholders, unlike directors, owed no fiduciary duties with respect to the company or their fellow shareholders. In the absence of this directorial duty, which existed long before the oppression remedy, Wallace $\mathrm{J}$. held that the majority shareholders had "... only done that which they have a legal right to do." 43 The respondents tried to avoid liability by stressing their shareholder positions to the exclusion of their directorships. In answer to this, Wallace J. stated that a member's actions would, nevertheless, be subjected to equitable considerations, although legally proper, if they were oppressive or unjust to another member and if they conflicted with the actor's duties as director ${ }^{44}$ The Court has made it excessively clear that directors' duties are a necessary ingredient for liability by classifying the breach of these duties as the oppressive or prejudicial conduct. The theory of the majority being forced to regularly consider the minority's best interests before acting does not survive the tone of this decision. ${ }^{45}$

42. (1983) 21 B.L.R. 246 (B.C.S.C.).

43. Id. at 252 .

44. Id. at 253.

45. Beck, supra n. 3 at 317; Waldron, supra n. 4 at 145-146; and C.M. Ravinsky, "The Statutory Protection against Oppression" in Corporate Structure, Finance and Operation (1981) 51 at 78.

Also on this point see the decision of Miller v. F. Mendel Holdings, supra n. 40 at 696, in which case relief was granted to minority shareholders under s. 234 of the Saskatchewan Business Corporations Act, R.S.S. 1978. c. B-10. Wimmer J. stated that had the only grounds for application been the adverse changes to the existing shareholders' rights, the order might have been refused. The majority shareholder's removal of the minority shareholders as directors was also held to be of "not much significance", as the applicants could not insist upon being directors; that is, they could not insist upon maintaining their position within the corporation. The judgement emphasized the basis for relief as being a transaction by the majority shareholder, also the sole director, which was plainly not in the best interests of Mendel Holdings or its shareholders, and which, incidentally, placed the director in a glaring conflict of duty situation. 
A second case that diminishes the duty of the majority theory is Jackman v. Jackets Enterprises Ltd. ${ }^{46}$ Jackets had been set up as a company to acquire property for development and then to lease it to Big Ben's, a company owned solely by the majority shareholder, who was also the director of Jackets. The minority shares had been given to the applicant as a gift, due to her husband's lengthy employment at Big Ben's. Mr. Jackman was dismissed nine years later and since that time the applicant had not received the necessary information as to the running of the company. There were loans and mortgages secured for the benefit of Ben's on which the applicant received no income, but the director, as owner of Ben's, gained all advantages. The majority shareholder and director had placed himself in a conflict of duty situation, especially since Ben's held no equity with which to repay the loan. Under s. 221 of the British Columbia Company Act the director was ordered to personally guarantee the loan and to cause Ben's to pay the difference in interest which Jackets had incurred for Ben's benefit.

Three circumstances in this case are worthy of note. The application had requested that Jackets purchase the minority shares. This was not granted by Fulton J. because ". . . there was never that relationship which would establish an equitable, let alone legal right to be consulted in respect of the management ofthe company." 47 Referring back to Diligenti and cases considered within that decision, Fulton J. concluded that this was certainly not an incorporated partnership situation and consequently did not require the minority shareholder to have an ongoing voice in management. Once more we see the importance of the minority fitting itself under the established quasi-partnership doctrine to obtain the relief asked for. The second, and most important factor for our purposes, was that the majority shareholder also enjoyed a directorial position and the personal benefit he would eventually gain from the loans was in conflict with his capacity, not as a majority shareholder, but as a director. The third factor to note is that there were also breaches under other specific parts of the Act, such as the failure to hold proper meetings and the failure to keep the shareholders duly informed of company transactions. In one case, then, we can see the three touchstones for liability under the oppression remedies discussed in this paper, and find, yet again, that there is no new-found duty placed on the majority shareholder.

A third case which sheds light on the position of directors under the oppression sections is Johnston v. West Fraser, previously discussed. When overturned on appeal the Court suggested that had the promises made to Johnston emanated from directors, rather than just majority shareholders, liability would have attached. Bull J.A. said that ". . . neither the giving of the assurances nor any breach was in exercise of the directors' powers as such," ${ }^{48}$ and also noted that the person who did hold a directorship was not a party to the assurances. This makes perfect sense considering that the two cases Wallace $\mathbf{J}$. applied in the trial decision were not closely related to the facts of Johnston. Diligenti, as earlier

46. (1977) 4 B.C.L.R. 358 (S.C.).

47. Id. at 360 .

48. Supran. 31 at 86. 
noted, was completely based on a quasi-partnership analysis into which West Fraser could not fit. More for the present purposes, however, was $O$ 'Neill v. Dunsmuir Holdings Ltd., ${ }^{49}$ where any liability that was found attached to the directors of the company, and not merely to the majority shareholders.

\section{CONCLUSION}

In conclusion, one can see that a full examination of the case law does not unveil a recent trend of court interference with the internal workings of corporations. The corporate theory remains unmarred. Similar duties are being enforced today as were before the oppression remedies took their present form. We will rely on entrenched directors' duties and specific protections provided in other sections of the Acts. ${ }^{50}$ One should be wary upon forming a closely held corporation on the basis of an agreement of participation in management decisions. If none of the above elements is present, however, one doubts how successful an action taken against a majority shareholder will be on the basis that his acts were oppressive, unfairly prejudicial, or simply unfairly disregarded the interests of the minority. Although minority shareholders are now in a better position to obtain direct relief, the question remains whether there is also a duty running to them, from the majority, to protect minority interests. It is suggested that majority shareholders need not be unduly alarmed - as of yet. To date the courts have taken a conservative stance interpreting the scope of the oppression remedies. The years to come, however, may bring a comfort with the available remedies and a concomitant innovative approach to their implementation. ${ }^{51}$

49. Unreported, 20 February 1980, J.D. of Vancouver, S.C. A790662.

50. I.e., s. 199 of the Canada Business Corporation Act as discussed earlier.

For further illustration of this point see R. v. The Sands Motor Hotel Limited (1984) 84 D.T.C. 6464 (Sask. Q.B.), in which case an application under s. 234 of the Saskatchewan Business Corporations Act, supra n. 45, was successful on behalf of the Crown as a creditor in regard to income tax purposes. The corporation issued dividends in contravention of $s$. 40 and redeemed certain preferred shares in contravention of $s .34$, both provisions of the same Act. The relevant sums were ordered returned under s. 234, however, the decision clearly rested on the above prohibitions in other sections of the Act.

See also Re Romana Inn Ltd. v. Apostal et al. (1982) 48 B.C.L.R. 65 (B.C.S.C.), in which case the respondents were ordered to pay the applicant one quarter of the net proceeds from a sale of the sole asset of the company which should only have been disposed of after a special resolution of all the shareholders.

An additional example, of the use of the oppression remedy based on a protective provision in another section of the Act can be seen in Kummen v. Kummen-Shipman Ltd. (1982) 16 Man. R. (2d) 260 (Q.B.). In this case the judge held that although the facts did not represent a condition of oppression in the legal sense, s. 234(f) of the Corporations Act, S.M. 1976, c. 40 could be invoked as an alternate remedy on an application for winding up.

51. An example of just such an innovative approach can be seen in the recent case of Re Bury and Bell Gouinlock Ltd. (1984) 48 O.R. (2d) 57 (H.C.), affirmed on appeal (1985) 49 O.R. (2d) 91 (Div. Ct.), where a corporation was prevented from exercising its contractual right arising from a shareholder agreement to delay, for a period of twelve months, the purchase of the applicant's shares. Reasons for the delay were peculiarly within the knowledge of the respondent, who advanced no grounds to justify their decision. The Court held that this, in itself, satisfied the burden of the applicant, who was penalized by the delay. The most interesting aspect of this case is the Court's order notwithstanding the existence of a valid contract providing for the situation. This is the first reported decision of the Ontario courts dealing with the oppression remedy in s. 247 of the Business Corporations Act, S.O. 1982, c. 4 . 